\author{
急性膵炎の診断 \\ 一臨床現場に即したガイドラインをめざして一
}

北川 元二*

要 旨：急性膵炎の診断には来院時に十分な特異度と感度をもって診断ができ，かつ簡便 で短時間で結果が判明する検査法が理想とされる，血液検査では血中アミラーゼの測定は ほぼ満足できる検査法であるが，その限界を補うために測定可能な施設では血中リパーゼ の測定が望ましい．試験紙法による尿中トリプシノーゲン 2 の測定は急性腹症の鑑別診断 および急性膵炎診断の迅速化に有用であり, 今後期待されている検査法である. 画像診断 では, 造影 CT は膵炎の診断のみならず, 重症度判定にも重要な情報を与えてくれる. しか しながら，どこの施設でも CT 検査が 24 時間緊急で実施できるわけではない.さらに，わ が国ではヨード造影剤の添付文書において急性膵炎では造影剤の使用が原則禁忌となって いるので, ガイドラインでは何らかの解説を加える必要がある.

索引用語: 急性膵炎診断 血中膵酵素 造影 $\mathrm{CT}$ 検査

尿中トリプシノーゲン 2

はじめに

ガイドラインはわが国をはじめ広く全世界の論 文のなかでエビデンスレベルの高いものを中心 に, 広く当該疾患に関する知見をまとめ, 臨床現 場で使用可能なものにしていく必要がある. 急性 膵炎の診療ガイドライン ${ }^{1)}$ につても当初腹部救 急医学会で作成された原案をもとに日本膵蔵学会 および厚生労働省難治性膵疾患調査研究班を加え た 3 者が合同で，わが国の臨床現場の実情からあ まり乘離しないように検討を行った. 当然, 今回 の改訂作業においてもガイドラインを使用する臨 床医が違和感を持たないような内容にしていく必 要がある。

本稿では, 急性脺炎の診断に関する項目につい て, (1)現行のガイドラインの問題点を指摘, (2)急 性膵炎診療に関する最新のエビデンスについて検 討, (3)ガイドライン改訂の必要性とその方向付け をすることを中心に, 現行ガイドラインの内容に

*名古屋学芸大学管理栄養学部
そって検証したい.

\section{身体所見}

「臨床現場での病歴聴取, 身体診察を, すべての 患者に施行する：推奨度 $\mathrm{A} 」$

病歴聴取や身体診察の重要性は急性膵炎のみな らず，すべての疾患の診断の基本であるが，急性 膵炎では他の急性腹症の原因となる疾患との鑑別 診断が重要であり,さらにバイタルサインのわず かな変化も見落とさないことが, 重症化予知の第 一歩となるため, 病歴聴取と身体診察の重要性は きわめて高いといえる.

\section{膵酵素診断}

「急性膵炎の診断に対する血中アミラーゼの測 定：推奨度 A」

「血中アミラーゼの限界を補うための血中リ パーゼの測定 : 推奨度 $\mathrm{A} 」$

急性膵炎診断における血中膵酵素測定の有用性 についてはいうまでもないが, 血中アミラーゼの 限界については広く知られており, その限界を補 
Table 1 テストストリップによる尿中トリプシノーゲン 2 測定の急性腹症患者入院時検査における臨 床性能（文献 11 より引用）

\begin{tabular}{lccccc}
\hline \multicolumn{1}{c}{ 報告 } & $\begin{array}{c}\text { 症例数 } \\
\text { (急性膵炎例数 })\end{array}$ & $\begin{array}{c}\text { 感度 } \\
(\%)\end{array}$ & $\begin{array}{c}\text { 特異度 } \\
(\%)\end{array}$ & $\begin{array}{r}\text { PPV } \\
(\%)\end{array}$ & $\begin{array}{c}\text { NPV } \\
(\%)\end{array}$ \\
\hline Hedström et al. 1996 & $154(57)$ & 91 & 95 & 91 & 95 \\
Kemppainen et al. 1997 & $500(53)$ & 94 & 95 & 68 & 99 \\
Kylänpää-Bäck et al. 2000 & $525(45)$ & 96 & 92 & 54 & 99 \\
Kylänpää-Bäck et al. 2002 & $237(29)$ & 93 & 92 & 63 & 99 \\
Pezzilli et al. 2001 & $90(30)$ & 53 & 100 & 100 & 81 \\
\hline
\end{tabular}

PPV : positive predictive value

NPV : negative predictive value

うために血中リパーゼの測定が有用であると欧米 を中心に報告されている采．しかしながら，欧米 における血中リパーゼの有用性に関するエビデン スは，現在わが国で使用されている測定法とは若 干異なる方法で得られたものであり，さらに，リ パーゼ測定については測定キットごとの数值の乘 離が問題になっている5.6). なお, リパーゼ測定法 についてはその標準化が日本臨床化学会の専門委 員会で検討されている段階である。わが国ではリ パーゼを自施設内で測定している病院はわずかで あり，現実問題としては緊急検査として使用する ことは不可能である. 従って, 急性膵炎の診断に おいてアミラーゼ測定が主体にならざるを得ない

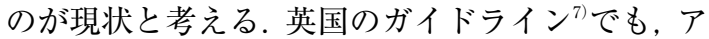
ミラーゼの測定で概ね問題はなく，リパーゼは測 定可能な施設において推奨されるとされている. リパーゼは急性膵炎における血中半減期がアミ ラーゼより長いため, 発症後 2,3 日後でも異常高 值を検出可能であることが診断精度を高めている と解説されており, 腹痛出現から 2,3 日経過して いる症例ではアミラーゼのみの測定では偽陰性の 可能性が出てくる.

急性膵炎の膵酵素診断における最近のトピック スとしては，尿試験紙法による尿中トリプシノー ゲン 2 測定とラテックス凝集法による血中エラス ターゼ 1 測定があげられる.

トリプシンの前駆体であるトリプシノーゲンに は数種類のアイソザイムが存在するが, 急性膵炎 時にはトリプシノーゲン 2 の血中濃度が増加する ことが知られている。 また，トリプシノーゲン 2 は尿細管での再吸収率が低いので尿中濃度はさら
に増加する．尿中トリプシノーゲン 2 の測定につ いては血中・尿中で定量的な測定法により急性膵 炎の診断および重症度診断における有用性が報告 されてきた ${ }^{48}$. その測定をさらに簡便・迅速化さ せる方法として 1996 年にフィンランドにおいて イムノクロマト法に基づく尿ディップスティッ ク・スクリーニング検査（以下，試験紙法）が開 発された ${ }^{99}$. 本法では尿に試験紙を入れるだけな ので, 特殊な測定装置は不要で, また, 検査に要 する時間は 5 分なので, 繰り返し検査可能である し，ベッドサイドでの検査も容易である。 トリプ シノーゲン 2 の試験紙法を用いた定性的測定法に よる急性膵炎診断の感度および特異度は ELISA による定量的トリプシノーゲン 2 測定法と同程度 で血中・尿中アミラーゼ検査より高かった（Table 1) $)^{10,11)}$ ．わが国では認可申請中であるが, 急性 膵炎のスクリーニング試薬としてはフィンランド をはじめ欧州各国, アジア（中国，韓国など）で すでに臨床応用されている.

エラスターゼ 1 は血中膵酵素であるが, 膵頭部 の切除可能な膵癌において異常高値を示すことか ら腫瘍マーカーとして臨床応用されてきた ${ }^{12,13}$. エラスターゼ 1 はアミラーゼより感度・特異度が 高く, 他の血中膵酵素より血中半減期が長く, 肝 で代謝されるので腎機能に影響されにくい，とい う特徵を有している。 エラスターゼ 1 はトリプシ ンと同様に RIA 法により測定されるため, 特殊な 機器を必要とし測定時間がかかるので, 緊急スク リーニング検査に用いることができなかった．近 年, ラテックス凝集法を用いたエラスターゼ 1 の 測定系が開発され，緊急検査が可能となった ${ }^{13.14)}$. 


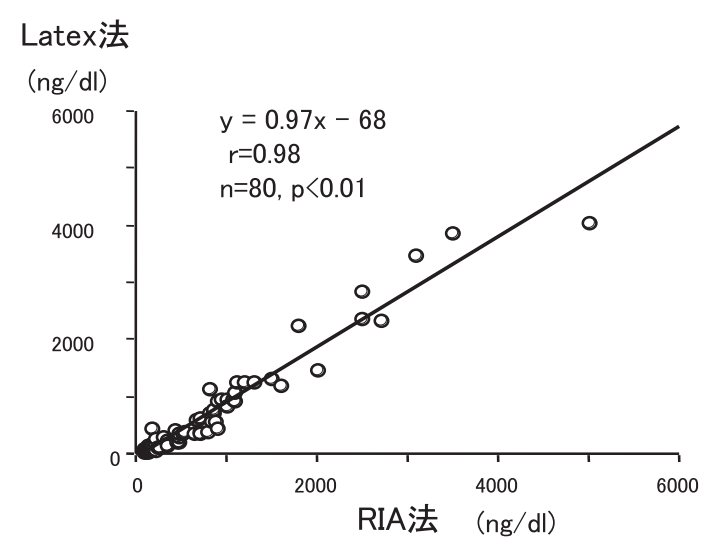

Fig. 1 ラテックス凝集法と RIA 法による血中エラス ターゼ 1 の測定（文献 14 より引用）

この新しい測定法では, エラスターゼ 1 に特異的 な, エピトープの異なる 2 種類のモノクローナル 抗体をラテックスに感作し, ラテックス試薬を作 成し, エラスターゼ 1 とラテックス粒子の免疫学 的反応により，ラテックス粒子が凝集し，凝集塊 が形成されることを応用している。この凝集塊を 汎用の自動化学分析装置で波長（主/副 $=570 / 800$ $\mathrm{nm})$ により濁度の変化として定量的に測定する. 測定時間はプレインキュベーション 5 分, 測定 5 分で全反応 10 分である. 従来の RIA 法による測 定值とラテックス凝集法による測定值の相関はき わめて良好である $\left(\right.$ Fig. 1) ${ }^{14)}$. 本法ではどこの病 院の臨床化学検査室にもある測定装置で他の緊急 生化学検査項目と同時に測定できるという利点が ある. 本法による血中エラスターゼ 1 の測定は急 性膵炎の緊急検査のみならず, 人間ドック等の膵 疾患のスクリーニング検査としても有用である.

\section{画像診断}

「胸・腹部単純 $\mathrm{X}$ 線撮影 : 推奨度 $\mathrm{A}\rfloor$

「超音波検査 : 推奨度 $\mathrm{A} 」$

「急性膵炎の診断における CT : 推奨度 B」

「急性膵炎の発症期における診断を目的とした $\mathrm{ERCP}$ : 推奨度 $\mathrm{E}\rfloor$

わが国のガイドラインでは画像診断のうち胸・ 腹部単純 $\mathrm{X}$ 線撮影と超音波検查が推奨度 $\mathrm{A}, \mathrm{CT}$ 検査が推奨度 B になっている。この理由としては
急性腹症の鑑別診断を考えた場合にどこの施設で も, いつでも繰り返し実施可能という点が重視さ れている. しかしながら, 急性膵炎診断に関する 特異性の点からは腹部単純 X 線検査は診断能が 低い. また, 超音波検査も急性膵炎の際の膵の描 出能は低く, 実用的ではない. 英国のガイドライ ン7では急性膵炎の診断に関して疑問がある場合 には, 超音波検査はしばしば有用ではなく, 一方, 造影 CT 検査は急性膵炎の有無についての証拠を 示すことが可能であるとして, 造影 CT 検查が推 奨度 $\mathrm{A}$ になっている. さらに, 腹部単純 $\mathrm{X}$ 線検査 は急性膵炎の診断には役に立たず, 超音波検査で は膵の腫大を認めることがあるが, 急性膵炎の際 の膵描出能は 25〜 50\% であると解説している.

造影 CT は膵炎の診断のみならず, 重症度診断 にも重要な情報を与えてくれる．しかしながら, どこの施設でも CT 検査が 24 時間緊急で実施で きるわけではない.さらに, わが国の造影剤の添 付文書には, 急性膵炎はヨード造影剂の原則禁忌 (投与しないことを原則とするが, 特に必要とする 場合には慎重に投与すること）となっている（症 状が悪化するおそれがある). 従って, わが国で造 影 CT を推奨度 A とすることについては若干問 題がある. ガイドラインでは急性膵炎患者の CT 検査の際に造影剤を使用する必要性について解説 を加える必要がある.

$\mathrm{MR}$ 検查は CT 検查に比較し, 検查時間が長い, 緊急検査体制が未整備, 人工呼吸器や輸液ポンプ などの通常の医療機器の金属製品を取り外さなけ ればならない, などの問題点を解決する必要があ るが, 新しい撮像方法の開発や造影 MRの可能性 については検討の必要がある.

$$
\text { まと め }
$$

急性脺炎では診断を迅速に行い, 可及的速やか に病態に即した治療を開始することが予後の改善 につながる. それぞれの検査法の特徵と限界を理 解し, 総合的に診断することが重要である.

\section{文献}

1）急性膵炎の診療ガイドライン作成委員会編. エビデン スに基づいた急性膵炎の診療ガイドライン。第 1 版. 
東京：金原出版, 2003.

2) Whitcomb DC. Clinical practice. Acute pancreatitis. N Engl J Med 2006 ; $354: 2142-50$.

3) Kingsnorth A, O'Reilly D. Acute pancreatitis. BMJ $2006 ; 332: 1072-6$.

4) Matull WR, Pereira SP, O’Donohue JW. Biochemical markers of acute pancreatitis. J Clin Pathol 2006 ; $59: 340-4$.

5）三宅一徳.リパーゼ. 臨床病理レビュー特集第 116 号最新酵素・アイソザイム検査一測定法とその臨床 的意義. 2001：90-9.

6）白井秀明, 桑 克彦, 渡辺伸一郎. リパーゼ測定の評 価. 日本臨床検査自動化学会会誌 $2002 ； 27 ： 115-9$.

7) UK Working Party on Acute Pancreatitis. UK guidelines for the management of acute pancreatitis. Gut $2005 ; 54 ; 1-9$.

8) Itkonen O, Koivunen E, Hurme M, Alfthan H, Schroder T, Stenman UH. Time-resolved immunofluorometric assays for trypsinogen-1 and 2 in serum reveal preferential elevation of trypsinogen- 2 in pancreatitis.
J Lab Clin Med $1990 ; 115$ : 712-8.

9) Hedstrom J, Korvuo A, Kenkimaki P, et al. Urinary trypsinogen-2 test strip for acute pancreatitis. Lancet $1996 ; 347: 729-30$.

10) Kemppainen EA, Hedstrom JI, Puolakkainen PA, et al. Rapid measurement of urinary trypsinogen-2 as a screening test for acute pancreatitis. N Engl J Med 1997 ; $336: 1788-93$.

11) Kylänpää-Bäck ML, Kemppainen E, Puolakkainen $P$ M-L. Trypsin-Based laboratory methods and CAPAP in acute pancreatitis. J Pancreas (Online) $2002 ; 3$ : 34-48.

12）早川哲夫, 近藤孝晴, 柴田時宗, 北川元二. 膵疾患 血清酵素診断. 臨床病理 $1991 ; 89: 35-48$.

13）北川元二, 成瀬 達, 石黒 洋, 早川哲夫. 膵疾患の 診断における膵酵素診断の臨床的意義. 日本臨床検査 自動化学会会誌 $2002 ; 27: 120-3$.

14）北川元二, 成瀬 達, 石黒 洋, 他. ラテックス凝集 法による血清エラスターゼ 1 測定の臨床的意義. 胆と 膵 $2002 ; 23: 567-71$.

\title{
Current concept for diagnosis of acute pancreatitis
}

\author{
Motoji KitaGAWA*
}

Key words : Acute pancreatitis, Diagnosis, Serum pancreatic enzymes, Contrast-enhanced computed tomography, Urinary trypsinogen 2

For the diagnosis of acute pancreatitis, the measurement of serum amylase is widely employed and it provides acceptable accuracy. The determination of serum lipase is more reliable, but lipase assay has some problems. A urinary dip stick for trypsinogen-2, with very high sensitivity and specificity, has been developed and it may be an ideal method for the diagnosis of acute pancreatitis. Imaging study is useful for the differential diagnosis of acute abdomen. Ultrasonography is often unhelpful because the pancreas can be visualized in only half of the patients with acute pancreatitis. Pancreatic imaging by contrast enhanced CT is very useful for the diagnosis and stratification of the severity of acute pancreatitis, but the use of contrast media may have undesirable effects on such patients.

\footnotetext{
* Department of Nutritional Sciences, Nagoya University of Arts and Sciences（Nisshin）
} 